\title{
PELAKSANAAN IZIN PERUBAHAN PENGGUNAAN TANAH TERHADAP ALIH PENGGUNAAN TANAH PERTANIAN KE RUMAH TINGGAL DI KANTOR BADAN PERTANAHAN NASIONAL/ AGRARIA DAN TATA RUANG KABUPATEN DEMAK
}

\author{
Akril Setiawan \\ Email: akrilsetiawan216@gmail.com \\ Lathifah Hanim \\ Dosen Fakultas Hukum Unissula \\ Email : lathifahhanim@yahoo.com
}

Mahasiswa Program Magister (S2) Kenotariatan Fakultas Hukum Unissula

\begin{abstract}
ABSTRAK
Izin Peruntukan Penggunaan Tanah adalah izin yang wajib dimiliki oleh setiap warga masyarakat yang akan mengubah tanah pertanian menjadi non pertanian. Fungsi dari izin peruntukan penggunaan tanah adalah untuk menekan serta pengendalian alih fungsi lahan yang terjadi. Tanah sawah (tanah pertanian) yang akan diubah ke non pertanian tentunya haruslah sesuai dengan rencana tata ruang dan wilayah Kabupaten Demak agar terjadi kesimbangan dimasa mendatang. Muncul masalah yaitu tentang pelaksanaan izin alih fungsi lahan di Kabupaten Demak dan antisipasi Pemerintah Kabupaten Demak dalam mengurangi alih fungsi lahan. Penelitian ini bertujuan untuk mengetahui pelaksanaan izin perubahan penggunaan tanah terhadap alih penggunaan tanah pertanian ke rumah tinggal. Untuk mengetahui hambatan-hambatan dan solusi dalam pelaksanaan izin perubahan penggunaan tanah terhadap alih penggunaan tanah pertanian ke rumah tinggal

Pendekatan penelitian menggunakan metode pendekatan secara yuridis empiris dan Spesifikasi penelitian ini menggunakan metode deskriptif analisis. Dalam penelitian ini menggunakan metode analisis data secara kualitatif.

Berdasarkan hasil penelitian yang dilakukan, dapat diketahui bahwa pelaksanaan izin perubahan penggunaan tanah terhadap alih penggunaan tanah pertanian ke rumah tinggal Di Kantor Badan Pertanahan Nasional/Agraria Dan Tata Ruang Kabupaten Demak telah sesuai antara regulasi. Hambatan-hambatan dalam pelaksanaan izin perubahan penggunaan tanah terhadap alih penggunaan tanah pertanian ke rumah tinggal di Kabupaten Demak yaitu 1) Kendala Koordinasi Kebijakan, 2) Kendala Pelaksanaan Kebijakan dan 3) Kendala Konsistensi Perencanaan. Upaya Pemerintah Demak dalam mengendalikan alih fungsi tanah pertanian menjadi tanah non-pertanian adalah dengan pensertipikatan tanah bagi petani yang bertujuan memberikan kepastian hak dan kepastian hukum atas kepemilikan tanah yang dikuasai masyarakat petani dan masyarakat secara cepat, tepat, mudah, murah dan aman

Kata Kunci : Izin, Perubahan Penggunaan Tanah, Alih Penggunaan Tanah Pertanian Ke Rumah Tinggal
\end{abstract}

\section{A. PENDAHULUAN}

\section{Latar Belakang}

Tanah atau ketersediaan lahan merupakan aset terpenting bagi kegiatan pertanian, kenyataannya pemerintah kurang memperhatikan hal ini. Kepemilikan tanah sebagai pilar terpenting kegiatan produksi semakin lama kian tidak ramah dengan kebutuhan sektor pertanian. Rata-rata, lahan kepemilikan pertanian semakin berkurang, bahkan di Jawa Tengah rata-rata kepemilikan lahan itu hanya 0,25 hektar. $^{1}$ Semakin berkurangnya (menyusutnya) kepemilikan lahan tersebut indikasi yang rasional yaitu bersumber dari pola warisan yang membuat lahan terfragmentasi, infiltrasi sektor industri atau jasa

1 Widhi Handoko, 2015, Seminar Nasional "Karya Motivasi, Pemikiran strategis, Dan Rencana Program Pengembangan Badan Pertahanan Nasional (BPN) RI', Semarang : 28 Maret 2015. semakin hari semakin menguras setiap jengkal lahan dan kebijakan pemerintah (khususnya BPN) yang mengabaikan dan bahkan meninggalkan sektor pertanian $^{2}$

Melihat keadaan tersebut di atas, pembangunan di Indonesia khususnya di beberapa wilayah perkotaan tertentu, harus memiliki suatu perencanaan atau konsep tata ruang, yang dulu sering disebut dengan master plan, di mana konsep tersebut sebagai arahan dan pedoman dalam melaksanakan pembangunan, sehingga permasalahan yang akan timbul yang diakibatkan dari hasil pembangunan akan dapat diminimalisir. Namun demikian, konsep tata ruang sebagai pedoman dan arahan pembangunan sebagian besar masih belum menunjukkan hasil sesuai

2 Ibid,. 
dengan tujuan dan arahan yang ditetapkan. ${ }^{3}$

Selain adanya keterbatasan lahan, permasalahan tata ruang semakin rumit karena kondisi perekonomian Indonesia pada saat ini maka perlu diwaspadai, terutama yang berkaitan dengan para pelaku kegiatan bisnis dalam penggunaan dan pemanfaatan ruang yang kian besar. ${ }^{4}$ Oleh karena itu wilayah kesatuan Republik Indonesia harus dapat dimanfaatkan serta didayagunakan secara efektif dengan memperhatikan nilai nilai konsep dasar manusia, masyarakat, serta ekosistem yang terdapat di Indonesia.

Kabupaten Demak adalah salah satu Kabupaten di Provinsi Jawa Tengah mempunyai Rencana Tata Ruang Wilayah (RTRW) yang dituangkan dalam Peraturan Daerah Nomor 6 Tahun 2011 tentang Rencana Tata Ruang Wilayah Kabupaten Demak tahun 2011-2031. Fakta fakta di lapangan menimbulkan pertanyaan mengenai bagaimana aturan yang dipakai oleh Badan Pertanahan Nasional sebagai pertimbangan dalam pemberian izin perubahan penggunaan tanah dari tanah pertanian ke rumah tinggal. Berangkat dari latar belakang tersebut

\section{Perumusan Masalah}

1. Bagaimana pelaksanaan izin perubahan penggunaan tanah terhadap alih penggunaan tanah pertanian ke rumah tinggal di Kantor Badan Pertanahan Nasional/Agraria dan Tata Ruang Kabupaten Demak ?

2. Apa hambatan-hambatan dan solusi dalam pelaksanaan izin perubahan penggunaan tanah terhadap alih penggunaan tanah pertanian ke rumah tinggal Kantor Badan Pertanahan Nasional/Agraria dan Tata Ruang Kabupaten Demak?

\section{Metode Penelitian}

Metode pendekatan yang digunakan dalam penelitian ini adalah metode pendekatan yuridis empiris. ${ }^{5}$ Menurut pendekatan empiris pengetahuan didasarkan atas fakta-fakta yang diperoleh dari hasil penelitian dan observasi. ${ }^{6}$ Spesifikasi penelitian yang digunakan adalah penelitian deskriptif analitis. ${ }^{7}$ Dalam penelitian ini penulis memilih metode analisis data secara kualitatif.

3 Juniarso Ridwan dan Achmad Shodik, 2013, Hukum Tata Ruang, Nuansa, Bandung, hal.21

4 Ibid.

5 Ronny Hanitijo Soemitro, 2001, Metodologi Penelitian Hukum dan Jurimetri, Ghalia Indonesia, Jakarta, hal 10.

6 Ronny Kountur, 2007, Metode Penelitian untuk Penulisan Skripsi dan Tesis, PPM, Jakarta, hal 6.

7 S. Margono, 2008, Metodologi Penelitian Pendidikan, Rineka Cipta, Jakarta, hal.37

\section{B. PEMBAHASAN}

1. Pelaksanaan Izin Perubahan Penggunaan Tanah Terhadap Alih Penggunaan Tanah Pertanian Ke Rumah Tinggal di Kantor Badan Pertanahan Nasional/Agraria dan Tata Ruang Kabupaten Demak

Demak sebagai salah satu kabupaten di Jawa Tengah terletak pada koordinat 6043'26' - 7009'43" Lintang Selatan dan 110027'58" - 110048'47" Bujur Timur. Wilayah ini sebelah utara berbatasan dengan Kabupaten Jepara dan Laut Jawa, sebelah timur berbatasan dengan Kabupaten Kudus dan Kabupaten Grobogan, sebelah selatan berbatasan dengan Kabupaten Grobogan dan Kabupaten Semarang, serta sebelah barat berbatasan dengan Kota Semarang. Wilayah hutan di Kabupaten Demak seluas 1.572 ha. Pada Rencana Tata Ruang Wilayah (RTRW) Kabupaten Demak Tahun 2011-2031, struktur tata ruang Kabupaten Demak dibagi dalam 5 (lima) Sub Wilayah Pembangunan (SWP), yaitu:

a. SWP I, meliputi wilayah Kecamatan Sayung, Kecamatan Karangtengah, Kecamatan Demak, dan Kecamatan Wonosalam dengan pusat pelayanan di Kawasan Perkotaan Kawasan Perkotaan Demak;

b. SWP II, meliputi wilayah Kecamatan Mranggen, Kecamatan Karangawen, dan Kecamatan Guntur dengan pusat pelayanan di Kawasan Perkotaan Mranggen;

c. SWP III, meliputi wilayah Kecamatan Wedung dan Kecamatan Bonang dengan pusat pelayanan di Kawasan Perkotaan Wedung;

d. SWP IV, meliputi wilayah Kecamatan Gajah, Kecamatan Karanganyar, dan Kecamatan Mijen dengan pusat pengembangan di Ibukota Kecamatan Gajah;

e. SWP V, meliputi wilayah Kecamatan Dempet dan Kecamatan Kebonagung dengan pusat pengembangan di Ibukota Kecamatan Dempet. ${ }^{8}$

Alasan masyarakat mengajukan permohonan perubahan penggunaan tanah antara lain:

a. Dikeluarkannya peraturan mengenai perubahan penggunaan tanah dari tanah pertanian ke non pertanian yang diatur dalam Surat Edaran Menteri Nomor 590/11108/SJ tahun 1984 tentang perubahan tanah pertanian ke non pertanian, yang ditindaklanjuti dengan peraturan yang lebih lanjut berupa Instruksi Gubernur Jawa Tengah Nomor 590/107/1985 tentang pencegahan perubahan tanah pertanian ke non pertanian yang tidak terkendali dan Peraturan Bupati Demak Nomor 17 Tahun 2016 tentang Tata Cara Pemberian Izin Pemanfaatan Ruang.

\footnotetext{
8 Peraturan Bupati Demak Nomor 17 Tahun 2016 tentang Tata Cara Pemberian Izin Pemanfaatan Ruang.
} 
b. Dalam pola penggunaan tanah yang merupakan tanah pertanian akan sulit menjual secara de facto. Hal ini sebagaimana telah diatur dalam peraturan pertanahan akan berpengaruh pada si pemilik tanah dan lokasi tanah sebagai obyek jual-beli.

Alasan warga desa di Kabupaten Demak melakukan perubahan penggunaan tanah, yaitu:

a. Tanah pertanian tidak boleh dipecah-pecah. Tanah pertanian tidak boleh dipecah-pecah karena hal ini merupakan usaha dari pemerintah dalam fungsinya untuk mengendalikan produksi pangan. Tujuan utama dari adanya peraturan ini adalah untuk tetap menjaga produksi pada swasembada pangan agar dapat memenuhi kebutuhan masyarakat pada umumnya.

b. Adanya keterbatasan pemanfaatan tanah dalam keadaan tanah pertanian. Tanah dalam keadaan tanah pertanian memang memiliki keterbatasan dalam pemanfaatannya, karena tanah yang memang peruntukannya digunakan sebagai areal pertanian harus diusahakan sedemikian rupa seperti halnya tanah pertanian. Jadi setiap penggunaan tanah harus disesuaikan dengan ketentauan dan peraturan yang ada. Adapun keterbatasan dari pemanfaatan penggunaan tanah pertanian, misalnya saja untuk pembangunan berupa rumah tinggal mereka harus melakukan permohonan izin perubahan penggunaan terlebih dahulu sebelum mereka (masyarakat) mengusahakan tanah tersebut.

Prosedur tata cara beralih fungsinya lahan pertanian diatur dalam Peraturan Menteri Pertanian No.81/Permentan/OT.140/8/2013 Tentang Pedoman Teknis Tata Cara Alih Fungsi Lahan Pertanian Pangan Berkelanjutan sebagai berikut :

a. Tata cara Alih Fungsi Lahan Pertanian Pangan Berkelanjutan dapat dilaksanakan setelah memenuhi semua persyaratan dan kriteria.

b. Pemohon Alih Fungsi Lahan Pertanian Pangan Berkelanjutan di Kabupaten/kota mengusulkan kepada Bupati/Walikota. Untuk memberikan persetujuan, Bupati/Walikota dibantu oleh Tim verifikasi Kabupaten/kota yang keanggotaannya berasal dari Satuan Kerja Perangkat Daerah (SKPD) yang bertanggung jawab dalam bidang lahan pertanian, perencanaan pembangunan, infrastruktur, administrasi pertanahan dan instansi/lembaga terkait.

c. Pemohon Alih Fungsi Lahan Pertanian Pangan Berkelanjutan lintas Kabupaten/Kota dalam satu Provinsi setelah mendapatkan rekomendasi dari Bupati/Walikota mengusulkan kepada Gubernur.

d. Pemohon alih fungsi Lahan Pertanian Pangan Berkelanjutan lintas provinsi setelah mendapatkan rekomendasi dari Bupati/Walikota dan Gubernur mengusulkan kepada Presiden.

e. Usulan pada butir 2 sampai dengan 4 di atas disampaikan kepada Bupati/Walikota setelah mendapatkan persetujuan dari Menteri Pertanian.
Tata cara beralihfungsinya lahan pertanian di Kabupaten Demak melibatkan beberapa instansi terkait dalam Satuan Kerja Perangkat Daerah (SKPD) seperti Dinas Pertanian, Dinas Tata Ruang dan Kebersihan, Kantor Pertanahan, dan Kantor Pelayanan Terpadu. Izin pengalihfungsian lahan pertanian menjadi lahan perumahan di Kabupaten Demak terdapat dua jenis mekanisme yaitu; (1) Izin Perubahan Penggunaan Tanah; dan (2) Izin Lokasi.

Bentuk lain izin pengalihfungsian lahan pertanian adalah izin lokasi. Izin lokasi juga diatur pada Undang-Undang Nomor 1 Tahun 2011 tentang Perumahan dan Undang-Undang Nomor 26 Tahun 2007 tentang Penataan Ruang. Izin lokasi sebagai izin pemanfaatan ruang diatur dalam Pasal 26 Ayat (3) UUPR, yaitu RTRW Kabupaten menjadi dasar untuk penerbitan perizinan lokasi pembangunan dan administrasi pertanahan. Ketentuan Pasal 26 UndangUndang Nomor 1 Tahun 2011 mengatur bahwa izin lokasi merupakan salah satu syarat dalam pembangunan perumahan oleh penyelenggara pembangunan perumahan.

Persyaratan bagi pemohon yang ingin mengajukan izin perubahan penggunaan tanah pertanian ke non pertanian di Kantor Badan Pertanahan Nasional/Agraria dan Tata Ruang Kabupaten Demak dilaksanakan berdasarkan ketentuan dalam Instruksi Gubernur Kepala Daerah Tingkat I Jawa Tengah Tanggal 25 Maret 1985 Nomor 590/107/1985 tentang Pencegahan Perubahan Tanah Pertanian ke Non Pertanian yang tidak Terkendalikan. Prosedur-prosedur yang ditempuh oleh Kantor Badan Pertanahan Nasional/Agraria dan Tata Ruang Kabupaten Demak, baik prosedur administrasi maupun prosedur teknis telah dilaksanakan berdasarkan dengan ketentuan yang tertera dalam Instruksi Gubernur Kepala Daerah Tingkat I Jawa Tengah Tanggal 25 Maret 1985 Nomor 590/107/1985 tentang Pencegahan Perubahan Tanah Pertanian ke Non Pertanian yang tidak Terkendalikan.

Penetapan Surat Keputusan Izin Perubahan Penggunaan Tanah Pertanian ke Non Pertanian oleh Kepala Kantor Badan Pertanahan Nasional/Agraria dan Tata Ruang Kabupaten Demak ditetapkan dengan pertimbangan-pertimbangan dikabulkan/tidaknya permohonan izin perubahan penggunaan tanah pertanian ke non pertanian mengacu pada Instruksi Gubernur Kepala Daerah Tingkat I Jawa Tengah Tanggal 25 Maret 1985 Nomor 590/107/1985 tentang Pencegahan Perubahan Tanah Pertanian ke Non Pertanian yang tidak Terkendalikan, dengan berdasarkan pertimbangan dari Panitia Pertimbangan Perubahan Penggunaan Tanah Pertanian ke Non Pertanian.

Adapun mengenai pengajuan permohonan izin perubahan penggunaan tanah pertanian ke non pertanian yang diajukan kepada Kantor Badan Pertanahan Nasional/Agraria dan Tata Ruang Kabupaten Demak guna mendapatkan Surat Keputusan 
Izin Perubahan Penggunaan Tanah Pertanian ke Non Pertanian dari Kepala Kantor Pertanahan memang tidak dilaksanakan berdasarkan ketentuan dalam Instruksi Gubernur Kepala Daerah Tingkat I Jawa Tengah Tanggal 25 Maret 1985 Nomor 590/107/1985 tentang Pencegahan Perubahan Tanah Pertanian ke Non Pertanian yang tidak Terkendalikan, yaitu diajukan kepada Bupati Demak guna mendapatkan Surat Keputusan Izin Perubahan Penggunaan Tanah Pertanian ke Non Pertanian dari Bupati Demak. Hal tersebut dikarenakan pada tahun 1985 (pada saat Instruksi Gubernur Kepala Daerah Tingkat I Jawa Tengah Tanggal 25 Maret 1985 Nomor 590/107/1985 tentang Pencegahan Perubahan Tanah Pertanian ke Non Pertanian yang tidak Terkendalikan dikeluarkan), Direktorat Jenderal Agraria termasuk kedalam satu lingkungan Departemen Dalam Negeri, sehingga urusan pertanahan ditangani oleh Departemen Dalam Negeri. Sekarang semua urusan pertanahan ditangani oleh Badan Pertanahan Nasional sebagai instansi independen.

2. Hambatan-hambatan dan Solusi Dalam Pelaksanaan Izin Perubahan Penggunaan Tanah Terhadap Alih Penggunaan Tanah Pertanian Ke Rumah Tinggal Di Kantor Badan Pertanahan Nasional/Agraria dan Tata Ruang Kabupaten Demak

Terdapat tiga kendala mendasar yang menjadi alasan mengapa peraturan pengendalian alih fungsi lahan sulit terlaksana, yaitu :

a. Kendala Koordinasi Kebijakan. Di satu sisi pemerintah berupaya melarang terjadinya alih fungsi lahan, tetapi di sisi lain justru mendorong terjadinya alih fungsi lahan tersebut melalui kebijakan pertumbuhan industri/manufaktur dan sektor non pertanian lainnya yang dalam kenyataannya menggunakan tanah pertanian.

b. Kendala Pelaksanaan Kebijakan. Peraturanperaturan pengendaliah alih fungsi lahan baru menyebutkan ketentuan yang dikenakan terhadap perusahaan-perusahaan atau badan hukum yang akan menggunakan lahan dan atau akan merubah lahan pertanian ke nonpertanian.

c. Kendala Konsistensi Perencanaan. RTRW Demak yang kemudian dilanjutkan dengan mekanisme pemberian izin lokasi, merupakan instrumen utama dalam pengendalian untuk mencegah terjadinya alih fungsi lahan sawah beririgasi teknis.

Kendala yang dihadapi Kantor Badan Pertanahan Nasional/Agraria dan Tata Ruang Kabupaten Demak dalam memproses perubahan penggunaan tanah pertanian ke non pertanian

1. Kurangnya pemahaman dari masyarakat tentang arti pentingnya izin perubahan penggunaan tanah.

2. Adanya perbedaan kepentingan tentang tujuan serta maksud dari pengendalian penggunaan tanah pertanian dengan kepentingan dari pihak pengembang pembangunan.

3. Kantor pertanahan dan instansi-instansi lain yang berperan dalam izin perubahan penggunaan tanah kurang mengawasi dan kurang monitoring terhadap lahan-lahan pertanian.

4. Realisasi pemberian izin perubahan penggunaan tanah yang tidak sesuai dengan surat keputusan pemberian izin.

5. Lokasi yang akan diajukan izin perubahan penggunaan tanah bertentangan dengan rencana tata ruang wilayah.

Secara empiris lahan pertanian di Kabupaten Demak yang paling rentan terhadap alih fungsi adalah sawah. Hal tersebut disebabkan oleh :

1) Kepadatan penduduk di Kabupaten Demak yang mempunyai agroekosistem dominan sawah pada umumnya jauh lebih tinggi dibandingkan agroekosistem lahan kering, sehingga tekanan penduduk atas lahan juga lebih tinggi;

2) Daerah pesawahan banyak yang lokasinya berdekatan dengan daerah perkotaan;

3) Akibat pola pembangunan di masa sebelumnya, infrastruktur wilayah pesawahan pada umumnya lebih baik dari pada wilayah lahan kering; dan

4) Pembangunan prasarana dan sarana pemukiman, kawasan industri, dan sebagainya cenderung berlangsung cepat di wilayah bertopografi datar,

Upaya Pemerintah Demak dalam mengendalikan alih fungsi tanah pertanian menjadi tanah nonpertanian di Kabupaten Demak adalah dengan pensertipikatan tanah bagi petani yang bertujuan :

a. Untuk memberikan kepastian hak dan kepastian hukum atas kepemilikan tanah yang dikuasai masyarakat petani dan masyarakat secara cepat, tepat, mudah, murah dan aman, sehingga terwujudnya penguatan status hak atas tanah petani yang semula berupa sebidang tanah dari predikat modal mati menjadi modal aktif .

b. Sertipikat hak atas tanah petani dapat digunakan sebagai alat penjaminan bagi petani dalam rangka penguatan kemampuan permodalan usahanya.

c. Untuk mewujudkan sasaran lahan pertanian abadi sehingga tidak mudah terjadinya alih fungsi lahan pertanian produktif ke non pertanian.

Ruang lingkup kegiatan penguatan hak atas tanah petani atau pensertipikatan lahan pertanian di Kabupaten Demak adalah :

a. Melakukan inventarisasi dan pendataan terhadap lahan sawah beririgasi, lahan sawah non irigasi serta lahan pertanian rakyat lainnya termasuk lahan kering dan lahan basah yang diperuntukkan sub sector tanaman pangan, hortikultura, perkebunan dan peternakan.

b. Melakukan pendataan terhadap petani/ pekebun/ peternak melalui kelompok tani, yang membutuhkan sertipikat lahan. 
c. Mengusulkan calon lokasi, jumlah bidang lahan serta petani/pekebun/peternak yang akan diajukan sebagai calon peserta pensertipikatan lahan pertanian.

d. Verifikasi terhadap calon peserta dan calon lokasi program pensertipikatan lahan petani.

\section{PENUTUP}

1. Simpulan

a. Pelaksanaan izin perubahan penggunaan tanah terhadap alih penggunaan tanah pertanian ke rumah tinggal di Kantor Badan Pertanahan Nasional/Agraria dan Tata Ruang Kabupaten Demak harus dengan izin dari Gubernur Kepala Daerah Tingkat I Jawa Tengah Cq. Kepala Direktorat Jenderal Agraria bagi tanah yang luasnya lebih dari 10.000 M2 dan Bupati/Walikotamadya Kepala Daerah bagi tanah yang luasnya $10.000 \mathrm{M} /$ kurang. Prosedur izin perubahan penggunaan tanah pertanian ke non pertanian adalah : (1) Pemohon mengajukan izin perubahan penggunaan tanah pertanian ke non pertanian di Kantor Badan Pertanahan Nasional/Agraria dan Tata Ruang Kabupaten Demak, (2) Seksi Penatagunaan Tanah sebagai sekretaris sebagai panitia pertimbangan IPPT menerima permohonan tersebut, (3) Rapat panitia pertimbangan IPPT, (4) Hasil rapat dituangkan dalam berita acara pertimbangan IPPT, (5) Kepala Kantor Pertanahan membuat SK IPPT, (6) Menyerahkan SK IPPT kepada pemohon.

b. Hambatan hambatan dalam pelaksanaan izin perubahan penggunaan tanah terhadap alih penggunaan tanah pertanian ke rumah tinggal di Kantor Badan Pertanahan Nasional/Agraria dan Tata Ruang Kabupaten Demak yaitu 1) Kendala Koordinasi Kebijakan, 2) Kendala Pelaksanaan Kebijakan dan 3) Kendala Konsistensi Perencanaan. Upaya Pemerintah Demak dalam mengendalikan alih fungsi tanah pertanian menjadi tanah non-pertanian adalah dengan pensertipikatan tanah bagi petani yang bertujuan memberikan kepastian hak dan kepastian hukum atas kepemilikan tanah yang dikuasai masyarakat petani dan masyarakat secara cepat, tepat, mudah, murah dan aman, sehingga terwujudnya penguatan status hak atas tanah petani yang semula berupa sebidang tanah dari predikat modal mati menjadi modal aktif.

2. Saran

a. Pemerintah Daerah Kabupaten Demak perlu menetapkan kebijakan yang lebih konsisten sehingga aparat pelaksana kebijakan tersebut dapat menjalankan tugas dengan pasti. Adanya dualisme kebijakan dapat menyebabkan kerusakan tatanan pembangunan daerah, khususnya mengenai kebijakan RUTRK/RDTRK/IKK. Pemerintah
Daerah Kabupaten Demak, tertib hukum dan administrasi harus diwujudkan, prinsip kehatikehatian dan kecermatan dalam mengeluarkan setiap kebijakan harus dipenuhi agar tidak ada lagi keputusan yang menyimpang dari hukum dan peraturan perundang-undangan yang ada.

b. Perlu dilakukan sosialisasi yang lebih menyeluruh kepada masyarakat Kabupaten Demak mengenai RUTRK/ RDTRK/IKK agar masyarakat mengetahui zonasi-zonasi daerah masing-masing sehingga akan menimbulkan kesadaran diri masyarakat untuk turut serta mengendalikan perubahan penggunaan tanah pertanian ke non pertanian.

c. Kantor Badan Pertanahan Nasional/Agraria dan Tata Ruang Kabupaten Demak diharapkan dapat lebih meningkatkan lagi sosialisasi mengenai izin perubahan penggunaan tanah yang dituangkan dalam bahasa yang sederhana yang dapat dipahami oleh masyarakat khususnya bagi masyarakat yang memiliki tingkat pendidikan rendah

\section{DAFTAR PUSTAKA}

\section{Buku-Buku}

Boedi Harsono, 1999, Hukum Agraria Indonesia, Djambatan, Jakarta

Ridwan HR, 2010, Hukum Administrasi Negara, PT RajaGrafindo Persada, Jakarta

Ronny Hanitijo Soemitro, 2001, Metodologi Penelitian Hukum dan Jurimetri, Ghalia Indonesia, Jakarta

Soedikno Mertokusumo, 1998, Hukum dan Politik Agraria, Karunika-Universitas Terbuka, Jakarta

Soerjono Soekanto,2010, Pengantar Penelitian Hukum, Penerbit Universitas Indonesia (UIPress), Jakarta

Yunus Wahid, 2014, Pengantar Hukum Tata Ruang, Kencana Prenadamedia Group, Jakarta

\section{Peraturan Perundang - Undangan}

Undang-Undang Dasar Negara Republik Indonesia Tahun 1945

Undang-Undang Nomor 5 Tahun 1960 tentang Peraturan Dasar Pokok-Pokok Agraria.

Undang-Undang Nomor 26 Tahun 2007 tentang Penataan Ruang. 
Undang-Undang Nomor 41 Tahun 2009 tentang perlindungan lahan pertanian berkelanjutan.

Peraturan Pemerintah Nomor 16 Tahun 2004 tentang Penatagunaan Tanah.

Peraturan Kepala Badan Pertanahan Nomor 4 tahun 2006 tentang Organisasi dan Tata Kerja Kantor Wilayah BPN dan Kantor Pertanahan.

Peraturan Kepala BPN Nomor 2 tahun 2011 tentang pedoman pertimbangan teknis pertanahan dalam penerbitan izin lokasi, penetapan lokasi, dan perubahan penggunaan tanah

Peraturan Gubernur Jawa Tengah Nomor 47 Tahun 2003 tentang petunjuk teknis kriteria, persyaratan, dan tata cara alih fungsi lahan pertanian pangan berkelanjutan.
Peraturan Bupati Demak Nomor 17 Tahun 2016 tentang Tata Cara Pemberian Izin Pemanfaatan Ruang

\section{Makalah/Karya Ilmiah}

Rachmani Puspitadewi, 2005, Hukum Perizinan, Fakultas Hukum, Universitas Komputer Indonesia, Bandung

Widhi Handoko, 2015, Seminar Nasional "Karya Motivasi, Pemikiran strategis, Dan Rencana Program Pengembangan Badan Pertahanan Nasional (BPN) RI", Semarang : 28 Maret 2015

\section{Internet}

Maria Ulfah, 2003, Deptan Menahan Laju Konversi Lahan Pertanian, dalam http://www.tempointeraktif. com (diakses tanggal 3 Januari 2017) 